\title{
Learning Difficulties in Listening Comprehension
}

\author{
Ryan Rayhana Sofyan' and Andi Mushrihah² \\ English Department, Universitas Negeri Makassar ${ }^{1}$ \\ English Department, STKIP, YPUP ${ }^{2}$ \\ Email: ryan.sofyan@unm.ac.id', andimushrihah@yahoo.co.id²
}

E-ISSN : 2579-4574

P-ISSN : 2549-7359

\begin{abstract}
This paper aims at describing the student's listening skill and their learning difficulties in listening comprehension. The method used was a descriptive method. The instruments were pre-TOEFL test and questionnaire. The population was the second year students of State University of Makassar. The results of this research are: the students have poor score in their listening comprehension and the students' learning difficulties in listening comprehension are: problem in interpretation, the lack of vocabulary, difficulty to concentrate, problem with lecturer's accent, confusion in similar phonemes, the speed of the speech problem in accent, problem in reduction and there are no repetitions and in learning media, the noise from students themselves, unclear sound, air conditioner problems and seat position. Based on the result, the writer concludes that the students' ability in listening comprehension is still poor, the teacher should motivate them to develop the habit of writing daily listening so that they can improve their skill.
\end{abstract}

Keywords: Learning difficulties, Error Analysis, Listening Comprehension, English Foreign Language

\section{https://ojs.unm.ac.id/eralingua}

\section{INTRODUCTION}

Listening comprehension is one of the language skills which is truly important to be studied. This skill uses the human hearing sense to communicate and understand each other. In hearing, sound waves are received as stimuli while listening requires an active interpretation of the stimuli that are received. The previous studies related listening comprehension had been conducted by Anwar (2018), Yavuz \& Arslan (2018), Mohammadzamani \& Taki (2018). Based on the studies, it can be concluded that Listening comprehension is an integrative and creative process of interaction given by the speaker and received by the listener, which contains linguistic or non-linguistic knowledge. Listening not only takes a role as a language skill in language performance but also a critical means in acquiring a second language in communication. It makes listening comprehension as an essential element in speech communication (Krashen et all., 2018; Goh, 2018; Bozorgian \& Alamdari, 2018).

At a glance, listening appears as a passive skill. In our daily life, as we associate with other people, communication become the most important thing. We share our feeling and ideas through speaking and expected that other people would listen and understand us, and so do we. To be able to listen well gives us confidence in communication. We can only talk sensibly when we can understand what is said to us. On the contrary, we may miss important information presented to us, or 
respond funnily. Listening in everyday life is a real-time skill. Unlike reading, we often do not have the chance to adjust the pace of speech, listen again or check an unknown word. The need to understand what we hear on the spot makes it even more crucial that we develop the ability to listen well. However, when it comes to foreign language learner where the language as the tool of the communication is something foreign and unusual, we have to put some more effort in teaching listening comprehension. There are also so many problems students have to face, such as errors or obstacle.

This study looks into the learning difficulties that inhibit the students from acquiring listening comprehension material. Based on the essential roles of translation explained above, the government, especially the National Education Ministry puts its policy to overcome this problem by instructing English to be taught from elementary school to university. Even nowadays, many kindergartens and playgroups introduce Basic English to their pupil. State University of Makassar, especially the English Department, Faculty of Languages and Literature, as one of state institution that giving English course to its students has been putting listening especially listening comprehension into its curriculum, includes listening comprehension I, listening comprehension II, and listening comprehension III, where it consists of two credits for each.

\section{RESEARCH METHOD}

This research employs a descriptive method, which involves collecting data in order to answer the research questions. As a descriptive study, it is neither threat the subject nor manipulate the data taken from the sample, because its primary purpose is to find out what are the problems in listening comprehension encountered by the students based on the result of the questionnaire given, and then give some solutions such learning strategies to solve those problems. Researcher used pre-TOEFL test and questionnaire as her research instrument in order to find out the difficulties encountered by students in listening comprehension.

The pre-TOEFL test is a standard test to measure the students' skills in listening comprehension. The test was developed by the Educational Testing Service office in United State of America that provided by the English Language Center of State University of Makassar and has never been taken before by the sample. The test consists of 50 items intended to examine students understanding of short conversations (30 items), long conversation (8 items) and short talks (12 items).

The students' opinions concerning learning difficulties in listening comprehension were collected through a questionnaire. The questionnaire consists of 17 items. They were intended to find out the students' learning difficulties relating to external and internal factors. The external factor includes learning difficulties related to learning materials, lecturer and media. Internal factor related to students themselves. 


\section{RESULTS AND DISCUSSION}

This section presents the discussion of the result of the data analysis. It is aimed at describing the students' skills in listening comprehension and their learning difficulties.

\section{Students' Ability in Listening Comprehension}

The description of the data collected through listening pre-TOEFL test, as explained in the previous section that shows the students' ability in listening comprehension. It is supported by the frequency and rate of percentage of the result of the students' score. The test score shows that among 20 students who had taken part as the research correspondents could obtain 40 as the mean score. It indicates that they belong to the fair achievement according to the score classification.

The achievement of the 20 students in the test is not satisfactory as no one of them got the score that can be categorized as "good" or "excellent". The mean score of the students is only 40. This score is far from 100, the highest mean score that can be achieved by the students. Statistically, the score of students is not normally distributed. Therefore, it can be said that the students have difficulties in listening comprehension. There are inhibiting factors that disable them to achieve a higher score. It is following the opinion of students collected through the research questionnaire.

\section{The Students' opinion on Learning Difficulties in Listening Comprehension}

This research found many difficulties experienced by students in listening comprehension based on the four main factors that affect listening process: Learning material, lecturer, students themselves, and media. In learning material, the difficulties were found in some aspects such as clustering, redundancy, reduced forms, performance variables, colloquial languages, rate of delivery, stress, rhythm and intonation and students opinion on the material difficulty level. The difficulties in this aspect are problems in interpretation, the lack of vocabulary, difficulty to concentrate, confusion in similar phonemes and the speed of the speech. The skill in interpreting requires students to have creative skills as they are required to process row material words into a significant meaning. According to River in Masna (2003), this process depends on three factors, namely: the linguistic information, the situation context and the comprehend message. Meanwhile, the difficulties in listening comprehension caused by the lack of vocabulary show that they are not ready to study the learning material given. The students' limitation of vocabulary inhibits them from exploring the information they listen because they have difficulty in the second step (understanding) of the four of listening processes: hearing, understanding, evaluating and responding.

Ther are some factors that can hinder students listening comprehension. These factors are: personal internal distraction, inattentiveness, positive or negative emotional responses toward the speakers, topic or occasion, detouring, jumping to conclusion about what a person is going to say before it is said, over-reacting to the language of the speaker, over-reacting to the message of the speaker, tending toward rebuttal, and rehearsing a response. These are the factors of the difficulty to concentrate (Goh, 2018; Chow et all., 2018; Lili, 2016; Vandergrift \& Baker, 2015). 
Concentration plays a vital role in listening comprehension because listening comprehension is a process which includes meaningful interactivity and an overall understanding of the text, so the students need to stay focus on what they hear. Confusion of the similar phonemes is the difficulty that rarely found or recognized by the teacher. This is related to the basic vocabulary of how the phoneme differs one word to another or even just to differ the classification of words such as noun and verb. Apparently, the students have been manipulated by similar phonemes. The last difficulty I have found in learning material is the speed of the speech. This difficulty is a common situation that students have to face in listening comprehension, especially when the learning materials were taken from the original language. So, the students need to accustom with the native speed of the speech.

While in lecturer's pronunciation, the difficulties are the lack of vocabulary, the problem with lecturer's accent, difficult to concentrate and the speed of the speech. Therefore, it is essential for the lecturer to be aware of their students difficulty and the lecturer should be more communicative to the students that could involve some various activities in the class such as asking questions and encouraging students to ask questions, nominating individual students to participate, encouraging group discussion followed by short reports, requesting short oral presentations, and making short quizzes. From a comprehension point of view, pauses give hearers more time to process what they need to understand. Research on the effect of pauses on lecture comprehension revealed that pauses facilitate listening. Moreover, they give listeners time to take a higher quantity of notes. The students' comments emphasize the vital role pauses play in their comprehension.

The learning media have an essential influence in the learning activity; in this case, the listening comprehension subject, which involves language laboratory. Commonly, the language laboratory is quite supportive of the students learning activity. But still, there are some disturbances such as the function of laboratory types of equipment (headset), the noise from students themselves, unclear sound, air conditioner problems and seat position. A large speaker in each laboratory solves the problem of the bad function of headset, but then again the seat position becomes a new disturbance because they affected by the position, the nearer the clearer. It makes the students that sit too far from the speaker have difficulty to hear the sound. The other difficulties, like the unclear sound from the speaker, become a problem for the students and also the air conditioner problem would make the students inconvenient doing their learning activity.

Some various activities can improve students listening skill.

The difficulties from students themselves based on their independent learning, such as their activity in listening to an English radio broadcast, watching English television show, watching English movie, listening English songs, joining group discussion and their habit in repeating tapes. There are various difficulties in this aspect such as the speed of the speech, problem in interpretation, the lack of vocabulary, the problem in accent, problem in reduction and there are no repetitions. One of the students' difficulties is the speed of the speech. The speed of the speech becomes a learning difficulty because of the character in the English radio broadcast, English television show, movies, songs commonly a native speaker. 
The lack of vocabulary also become a common difficulty in doing independent learning, because we listen directly from the native speaker in some different media, there are many new vocabularies for the students. Problem in interpretation is the next difficulty that also caused by the lack of vocabulary and the speed of the speech. The speed of the speech and lack of vocabulary affect this problem in interpretation because when the speech was continuing, the students feel panic and cannot interpret the message of the speech. So the students need to be accustomed to do these activities. Besides those difficulties problem in accent also inhibit the students acquiring listening comprehension, different kind of accents will confuse students. In their study on the problems facing students lecture comprehension, Flowerdew and Miller, (1992) indicated difficulty in concentration and maintaining concentration for a long time. This claim is supported by Underwood (1989), who stated that inability to concentrate "is a major problem because even the shortest break in attention can seriously impair comprehension." Goh (2018) reported learners' difficulty in perception: students faced problems on recognition of familiar words. They stated that although they were familiar with some words, they were unable to remember their meaning immediately. They also expressed difficulty in understanding the intended message though they were familiar with the literal meaning of words. Also noted were problems with processing the content of the message conveyed by the speaker because of lack of prior knowledge

Some studies conducted by Salleh et all. (2018), Tsang (2019), Moussalli \& Cardoso (2019) show that one of the learners' problems in listening comprehension is the various accent of the speaker. This issue has only happened temporarily. It can be overcome by repeated listening and practice the students' pronunciation by making the sound exactly like it is heard. One of the difficulties of this aspect is the students less of learning habits. Students with lousy learning habit need to be supported with some interesting strategies, such as listening to songs or watching movies because it seems that all the students are interested in these strategies. It can help the students to improve their listening skill by making them exciting and fun doing listening activities. There is one fact from this research, and the most critical finding is that the students are classified fair, but most of them think that they do not have difficulty in listening comprehension. From this fact, we can conclude that they do not realize their learning difficulties in listening comprehension. The students also need to be aware of the factors which contribute to their difficulties in listening. When listeners know something about their strategies, problems, and attitudes, they will be able to improve their listening practices and become better listeners. This could be a fascinating case that all the listening comprehension lecturers need to be aware of. So they can find a way to make the students aware of their difficulties and have the courage to talk about it and then find some listening strategies to solve those difficulties.

\section{CONCLUSION}

As mentioned earlier, this research aimed to explore the learning difficulties encountered by students in listening comprehension. The conclusion from this research as follows: 
1. The ability of students in listening comprehension is poor. Their average score is 40.4 from the highest possible score, 100. It reflects that the students have difficulties in listening comprehension. None of the students achieves the score from good or excellent category.

2. Various factors pointed by students as inhibitions in listening comprehension aspects such as: (1) problem in interpretation, the lack of vocabulary, difficulty to concentrate, confusion in similar phonemes and the speed of the speech in learning material; (2) the lack of vocabulary, problem with lecturer's accent, difficult to concentrate and the speed of the speech in lecturer's pronunciation; (3) the inadequate function of laboratory equipments (headset), the noise from students themselves, unclear sound, air conditioner problems and seat position in learning media; (4) the speed of the speech, problem in interpretation, the lack of vocabulary, problem in accent, problem in reduction and there are no repetitions in students' independent learning outside the class.

3. Listeners know something about their strategies, problems, and attitudes they will be able to improve their listening practices and become better listeners. Some students do not realize the difficulties they face in listening comprehension. They stated that they do not have any problems, but in fact, their scores are not in "good" or "excellent" category.

\section{REFERENCES}

Anwar, M. N. (2018). Acquisition of Skills for Listening Comprehension: Barriers and Solutions. International Journal of English Language and Literature Studies, 7(3), 50-54.

Bozorgian, H., \& Alamdari, E. F. (2018). Multimedia listening comprehension: Metacognitive instruction or metacognitive instruction through dialogic interaction. ReCALL, 30(1), 131-152.

Chow, B. W. Y., Chiu, H. T., \& Wong, S. W. (2018). Anxiety in reading and listening English as a foreign language in Chinese undergraduate students. Language Teaching Research, 22(6), 719-738.

Goh, C. C. (2018). Metacognition in second language listening. The TESOL Encyclopedia of English Language Teaching, 1-7.

Hasan, Ali. (2002). Learners' Perceptions of Listening Comprehension Problems. A thesis Damascus University.

Krashen, S., Renandya, W. A., Mason, B., \& Bose, P. (2018). Paths to competence in listening comprehension. Beyond Words, 6(1), 1-3.

Lili, Z. (2016). Influence of anxiety on English listening comprehension: An investigation based on the freshmen of English majors. Studies in Literature and Language, 11(6), 40-47.

Masna. (2003). The Interest of the Students in Listening Comprehension by Using Language Laboratory. A thesis FBS UNM Makassar.

Mohammadzamani, M., \& Taki, S. (2018). Developing Listening Skills through Input, Interaction and Output: Iranian EFL learners in Focus. Journal of Applied Linguistics and Language Research, 5(1), 90-99. 
Moussalli, S., \& Cardoso, W. (2019). Intelligent personal assistants: can they understand and be understood by accented L2 learners?. Computer Assisted Language Learning, 1-26.

Salleh, S. M., May, L. S., Azmi, A. S., Hatta, S. A. M., Razali, N., \& Zawawi, M. Z. M. (2018). Identifying Listening Problems and the Need for Technology Assisted Language Learning (TALL) to Improve Listening Skills among Diploma Students. International Journal of Modern Languages and Applied Linguistics, 2(1).

Tsang, A. (2019). Why English accents and pronunciation 'still'matter for teachers nowadays: a mixed-methods study on learners' perceptions. Journal of Multilingual and Multicultural Development, 1-17.

Vandergrift, L., \& Baker, S. (2015). Learner variables in second language listening comprehension: An exploratory path analysis. Language Learning, 65(2), 390416.

Yavuz, O., \& Arslan, A. (2018). Cooperative Learning in Acquisition of the English Language Skills. European Journal of Educational Research, 7(3), 591-600. 